\title{
The Contextualization of Hijrah Based on Maqashid Al-Syariah Perspective
}

\author{
H Husain \\ IAIN Bone, South Sulawesi, Indonesia \\ \{hukmiahusain@gmail.com\}
}

\begin{abstract}
Over time, the meaning of hijrah is increasingly varied according to the meaning of the present context. Hijrah in the millennial era is a term that emerges with changes in information consumption patterns via digital (social media). The widespread trends in the use of the term hijrah is because of the emergence of a call from preachers targeting young people and even adults as objects of awareness to become a better person, such as the Sahabat Hijrah Bone community (SHB).In this study, the meaning of the context of hijrah will be analyzed through the perspective of maqashid al-shariah as a way of knowing whether the phenomenon of hijrah is in accordance with the aims and objectives of sharia. Maqashid al-syari'ah consists of two words, maqashid and al-syari'ah. Maqashid is a plural form of al-qashdu which means the way to the source of water. Al-qasdu also means the path to the direction of the main source of life.
\end{abstract}

Keywords: Contextualization, Hijrah, Maqasid Al-Sharia

\section{Introduction}

Hijrah(or emigration in English)means to move [1]. Some of them interpret the word hijrah with flight even though the flight implicitly contains a negative stigma, because its connotation means to run away. The meaning of hijrah is much criticized by Muslim intellectuals because it is not in accordance with the substance of the Prophet's migration [2]. Another meaning of hijrahis al-tarku which means to leave something. In Islamic law, hijrah is interpreted as separating or moving from a kufr country to an Islamic country because of worrying about the safety of religion [3]. The word hajara also has a meaning of severing relations [4].

Al-Raghib al-Asfahani interpreted hijrah lexically to someone who left the other, physically, verbally, even psychologically [5]. According to Ibn Faris, migration is the opposite of washal, migration is also the departure of people from one region to another [6].

Prophet Muhammad Saw. said:

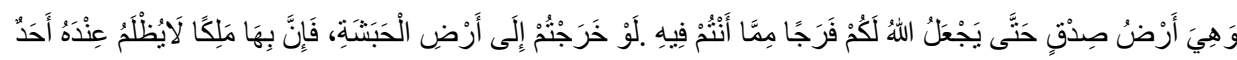

"You should migrate to the land of Habasyah, because there is a king where there is no one wrong by his side. Habasyah is a land of honesty where Allah will make it a solution for you from the suffering you experienced." [7]

The hadith above explains that a substantial hijrah does not always mean migrating from a pagan country to a Muslim country, but sometimes it means migrating because it preserves 
continuity of religion as part of the benefits of hifdzu al-din. Hijrah in the hadith above has a broad meaning in the context of an effort to realize the movement from bad things to good things, from bad circumstances to good conditions, from mafsadah to maslahah. Contextually, hijrah has a broad meaning and does not merely mean moving from an old domicile to a new domicile, as happened during the time of the Prophet, when Muslims moved from Mecca to Habasyah, so did the large-scale hijrah that occurred 10 years after the Prophet's prophethood, emigrated from Mecca to Yathrib / Medina.

The hijrah trend as a call for change is packaged in a variety of interesting variants such as dakwah in cafes, seminars, talk shows, ground coffee, to large-scale meetings such as the hijrah fiesta with the gathering of hijrah-loving communities. To maximize activities, public figures, such as ustadz or habib, even artists who proclaim themselves as part of the hijrah community, are invited because their dakwah is commonly loved and popular on social media. The existence of a public figure as a role model among young people also influences the hijrah interests of society, especially the younger generation. Invitations to hijrah in this modern era continue to roll in the middle of society and touch all segments and social strata.

The massive flow of the hijrah campaign in social media and visual media initiated the formation of communities in several areas which were spread not only in the capital but also in the regency cities.

The formation of hijrah community was accompanied by various taglines such as ayo hijrah, hijrah yuuk, and taglines that invite others. Various perceptions about the meaning of hijrah also cause pros and cons at various levels of society. Apart from the pros and cons of hijrah, it did not make the hijrah campaign subsided. It even became a topic of conversation since the last three years after the term was popular through social media. The hijrah movement campaign on social media can be seen by the proliferation of accounts affiliated with the hijrah invitations, such as the hijrah Instagram account which aims to recruit youth to join the hijrah community, because of youth as the most Instagram users as well as other accounts, such as Facebook and Twitter. An example that was accessed on an Instagram account including@pemudahijrahmakassar was followed as many as 12,200 followers, as many as 340 posts and even hijrah hashtags can be found in all provinces in Indonesia and almost all districts/cities in Indonesia have hijrah hashtags, as well as other migratory accounts. The hashtag of @pemudahijrah, managed to post as many as 3,800,000 posts, and the hashtag of @pemudahijrahbandung uploaded as many as 35,500 posts, and @hijrahquote shared as many as 464,000 posts and even the hijrah hashtag spreads as many as 8,000,000 posts, Indahnya_hijrah_bersama has 334,000 followers, and as many as 1.111 post, Hanan Attaki as the founder of SHIFT Pemuda Hijrah, has a follower of 7,600,000 people, with 715 pictures and lectures.

On Facebook, a page related to hijrah like pemuda hijrah was followed by 138,000 thousand followers. Pemuda Hijrah located in Mecca has 6,372 group members.The FB account of Pemuda Hijrah Shift, for example, has a tagline. The shift is a movement of pemuda hijrah who wants to leave the things that are forbidden by Allh Swt and become obedient youths. Sahabat Hijrah who has a tagline of QS.4: 100, with the mission of becoming a better human being, had as many as 51,748 followers. This account was created on April 3, 2012. The making of this account indicates that the hijrah campaign has basically been echoed in the last few years but the invitation for massive and popular hijrah is around the last three years. If it is calculated from the whole hijrah account followers spread over Instagram it could reach tens of millions. This figure continues to move from time to time, as an indicator that the hijrah campaign received a positive response, especially among millennials. 


\section{Method}

The type of this research is descriptive qualitative research by using phenomenology as a methodological approach. Phenomenology is assessment based on a study of the phenomenon by looking at and observing various subjective aspects of object behavior. This research is also related to natural observation by observing the behavior of the hijrah person either individually or communally.

Furthermore, researchers conducted data mining in the form of how object meaning gives meaning to related phenomena. Data mining is carried out through interviews with objects or informants deemed competent in the study. Data is also obtained through direct observation of the object of research, through social media and the social life of the surrounding community. Then the data is interpreted in a descriptive form.

In this study, object of phenomena will be analyzed using perspective of maqashid alshariah. This method is aimed to test the suitability of the phenomena caused by the subject to its object with the objectives of sharia, namely observing the phenomenon of hijrah movement in terms of context both in the real world and the virtual world by confronting a sharia perspective.

\section{Result and Discussion}

The Nature of Hijrah

Rasulullah SAW. said:

$$
\text { وَالْرُهَاجِرُ مَنْ هَجَرَ مَا نَهَهى اللهُ عَنْهُ }
$$

"The essence of hijrah is the person who abandons what is forbidden by Allah," (Muttafaq 'alayhi) [8].

Hijrah is essentially a tark al-manhiyyat, which means leaving what is prohibited by the Shari'a. It means thathijrah is not limited to the meaning of migrating outwardly, but also includes migrating inwardly (outward and inward changes) [9].

According to Quraish Shihab, hijrah is leaving the bad to the good. Hijrah is an expression of homeland love exemplified by the Prophet Muhammad Saw. For the Indonesian people, hijrah must be interpreted to love the motherland more to create a country that is just, peaceful and prosperous.

Hijrah was chosen for the Islamic New Year because it has three important values that must be understood by Muslims. Firstly, there is a link between hijrah and security because at that time there was terror or death threats against the Prophet and his followers.

Secondly, even though the hijrah was a direct command from Allah, the Prophet continued to plan before hijrah to Medina. According to him, before hijrah to Medina, the Prophet first moved to Habasyah (now Ethiopia) even though the country was led by a Christian king. Because the king was good and just, the Prophet ordered hijrah to Habasyah, before then hijrah again to Medina.

Thirdly, Quraish Shihab argued that in the hijrah there was togetherness because at that time there were children, teenagers, and parents. He asserted that the Islamic New Year began with a period of hijrah of the Prophet Muhammad, not when the Prophet won a victory [10]. In psychology, certain names or symbols provide suggestions and stimuli to someone. Thus, the name 'hijriyah' in the Qur'an is referred to by various derivations 27 times. The mention of 
isim is only 8 times, while the more number (19 times) is called fiil, eithermadhi, mudhari',oramr.

Today, according to Quraish Shihab, hijrah can be realized by creating a better life in all fields such as education, economy, social, ideology, in realizing a just and prosperous Indonesian society. Not hijrah to war, let alone killing fellow human beings [11], he also emphasized that in realizing hijrah it would require careful and good planning for the benefit of the nation and the motherland.

The meaning of hijrah for Quraish Shihab is more highlighted on the social side, compared to the ta'abbudi side. It covers a part of the Prophet'shijrah, which was preceded by physical and spiritual preparation to move from one region to another, from one condition to another, aimed at the realization of aqidah tauhid, the correct sharia, and morality and brilliant character. All these are a unity between the relationship of the servant with his Lord and the relationship of the servant with the servant, in accordance with the aims and purposes of the shari'a (comprehensive hijrah).

\section{Pros and Cons of Hijrah in Millennial Era}

The phenomenon of hijrah is one of the derivative impacts of government policies in the past. Ariel Heryanto, through his book Identitas dan Kenikmatan: Politik Budaya Layar Indonesia (2015) states that there has been a resurgence of Islamization towards the end of the New Order's rule. Islamic groups that were previously regarded as extreme right was later embraced and made new allies of the Suharto government to strengthen its political position which was currently weakening.

It was a time when using veil was no longer prohibited, and Islamic groups began to express their political aspirations openly without fear of being oppressed by the ruling regime. Hijrah, in this context, is a derivative impact of the policy.

The hijrah movement is a movement sponsored by the industry. It is no longer a secret that industry commodifies everything for sale, including religious observance. Before the massive hijrah campaign was carried out, the industry had already co-opted the religious observance of the community for commercial purposes. This can be seen from the production of clothing and various beauty products, such as soap, shampoo, and special makeup for Muslim women. These beauty products even hold various beauty contests specifically for veiled Muslim women [12].

There are two reasons for the movement of hijrah into massive movements, because there are opportunities that can accommodate the interests of "person of hijrah" and the observant of the clothing industry producing shar'i outfit with modern style and in accordance with millennial trends.

Apart from the impact that the fashion industry has had on the hijrah movement, the other side of the hijrah movement massively is due to the increasingly open opportunities to hijrah very easily through various means that can be accessed by everyone, such as opportunities through social media besides this movement is open to the public through community formation like as in Bone district. According to the main initiator Arfan, the Sahabat Hijrah Bone (SHB) community came from various backgrounds, including police, military, civil servant, businessmen, housewives, bankers and others. This community also consists of people from different religious organizations, such as the community of jamaah tabligh, Wahdah Islamiyah and others.

According to him, the spread of SHB's dakwah was not only in the mosque, but also in cafes and coffee shops, because SHB's targets were people who wanted to be better. An 
expertise to gather dakwah material and carefulness get people interested in involving with SHB. In refreshing the ties for this hijrah community, administrators of SHB initiate family gathering, bicycles and futsal competitions. Arfan as the initiator of the dawn prayer movement in congregation claimed that holding a hijrah community is a representation of his efforts to facilitate people who want to change from bad behavior to good behavior such as not performing the five daily prayers to become a Muslim who routinely performs the five-time prayer, from drunkards to leaving liquor and the like, from disobedience to obedience . It is based on his experience for decades as a Muslim because Islam is only listed on the identity card. The same thing was expressed by his wife about the different attitudes of Arfan pre and post hijrah.

It cannot be denied that the majority of people who participated in the hijrah were mostly from the upper middle class. The hijrah did not necessarily eliminate one's identity and preferences.As revealed by Ustadz Yusuf Khalid Da'i who cames from Pangkep regency, South Sulawesi that what interesting about this hijrah invitation is a fact that someone who participates in the hijrah can still wear their favorite clothes, such as luxury watches, branded shoes, outfit alloys favored. It means that person of hijrah does not change much, but change in their lives is his/her spiritual values, so that his/her appearance can still adjust to the surrounding conditions, and what changes from his habit is from not getting used to the mosque to becoming diligent to the mosque after hijrah . Moreover, the person of hijrah can still enjoy life on traveling abroad with several communities. For them, this wealth does not affect his spiritual, because basically they continue to recite in majelis taklim in several places.

It is different from what was conveyed by the two informants whose writers interviewed. Aksi Hamzah actually responded to the phenomenon of the hijrah movement as the existence of a phenomenon of saturation with the concept of hedonism in millennial circles. This saturation triggers a search for new patterns that are more elegant and capable of satisfying their inner self which has been empty with the current model of life. The hijrah movement became massive because of the emergence of the phenomenon of saturation in the concept of life.

The positive impact of the hijrah campaign began with the rise of millennial activities in a religious approach with packaging that was also in the millennial concept. For example it was hold a recitation at a café, and it was formed a community with shar'i outfits. Islamic symbols through style began to appear among young people such as happy to maintain beards and even trousers are symbols for young people who emigrated. The preservation of this symbolization according to the Hamzah Action, religion becomes crystallized in the world of fashion and entertainment rather than the content of Shariah teachings. The world of fashion cares with the phenomenon of the rise of people who emigrate but are ignorant of the rules of shari'a. Ustadz is more striking in the pattern of entertainment in the form of oral skills but poor in terms of substantial teaching content

During his interview, Aksi Hamzah also mentions some of the characteristics of the person of hijrah as follows: 1) Performing with certain communities; 2)Prioritizing symbolization rather than substance; 3)Insisting with certain propositions and being less tolerant of differences; 4) Exposuring to social activities; and 5)Delighting to upload and sharing the role models they follow

Apart from the pros and cons of the hijrah movement, the phenomenon of hijrah is not only being the target of economic development but hijrah has also become an identity achievement as a status of self-committed to beliefs relatively. 


\section{Maqashid Al-Sharia}

According to al-Syatibii, the goal of shari'a can be achieved by humans through two things. The first is through fulfilling the demands of the shari'a (taklifi), in the form of demands to realize Allah's commandment by carrying out them. The second is maintaining them and avoiding the restrictions in the shari'a [13], [14]. Associated to the definition of maqashid alshariah, al-Syatibi said that the shari'ah maker in determining the shari'a was aimed at realizing the benefit of His servants in the world and the hereafter as well.

The concept of al-Syatibi about maqashid al-sharia is basically aimed at realizing benefit for humans. In line with al-Syatibi's statement, Fathial-Darini revealed that the purpose of the law was made for the benefit of the people [15].

The content of maqashid al-shari'ah al-Syatibi is benefit. Emphasis on maqashid alshari'ah made by al-Syatibi generally starts from the content of the Quranic verses which shows that God's laws contain overall benefit [16].

Related to the statement above, Rasulullah Saw said, "لاضررو لاضرار", this hadith indicates the necessity to maintain benefit and prevent damage (mafsadah), because the synonym of dharar is mafsadah. Thus, if the Shari'a denies or prevents damage then it has become a necessity to realize benefits as maslahat. Between mafsadah and benefit (maslahat) are two opposites, and there is no mediator between the two.

The most powerful theorem in shari'a is nash and ijma'. Both may be in accordance with the maintenance of the benefit or may be contradictory. If both (nash and ijma) match the maintenance of the benefit, then it is good and there is no contradiction because the three are in line with the law. However, if both of them contradict the maslahah, then it is obligatory to prioritize the maslahah of both by way of takhsis [17] and the bayanof both by not canceling both as prioritizing the Sunnah rather the Qur'an by the method of bayan [17]. However, Najmuddin al-Thufy asserted that what was meant with prioritizing the maslahah of the texts and ijma related to mu'amalah not worship is a fact that worship is a special right for God. This right cannot be known with certainty about quantity, quality, time, and place except according to His instructions. In contrast to human rights, laws such as the siyasahsyar'iyyah are made for human benefit. Thus, benefit is what is taken and achieved its purpose [18].

Al-Syatibi divides this benefit (maqashid) into three important parts, namely dharuriyat (primary), hajiyat (secondary), and tahsiniyat (tertiary).

The Maqashid al-Dharuriyyat is something that must exist in order to realize the benefit of religion and the world. It is intended to eliminate difficulties or make maintenance of the five main elements. TheMaqashid Tahsiniyat is intended for humans to be able to do their best to perform the five main elements. If there is no Dharuriyat benefit, it will cause damage and even loss of life, such as eating, drinking, praying, fasting, and other worships. There are five maslahat or maqashidal-dharuriyat,i.e. religion (addin), soul (al-nafs), descendants (annasl), treasure (al-mal) and mind (al-aql) [16].

Maqashid al-sharia is always in line with the benefits and always puts the benefits in the first place. Maqashid al-syariah accommodated hijrah in the millennial era as an effort to move from a bad situation to a better one as President Joko widodo called for Indonesia to migrate from poverty to prosperity to migration to economic justice. According to him, everything still needs a non-instant process.

It is hijrah from inequality to economic justice. The hijrah for Indonesia needs a process. It cannot be in 1 and 2 years. There is a process. There are stages of magnitude. "In essence, trying hard to bring Indonesia to move from backwardness to progress," he added [19]. Other calls were also made for young entrepreneurs, asking young entrepreneurs to have productive 
behavior, not consumptive. The point of hijrah suggestion of the president is to invite Indonesian people to make Indonesia more prosperous. If this statement is analyzed by using maqashidal-sharia, it is categorized as part of the point of al-dharuriyat covering the maslahah 'ammah in hifdzal-nafs and hifdzal-mal.

The hijrah in context of the millennial era is an invitation and a call to make a move from bad habits and bad behavior to good habits and behavior, so that the benefits are realized in accordance with the goals and intentions of sharia and each individual can realize that benefit with the preservation of religion, soul, mind, descent and wealth. With the invitation to hijrah by the president is in line with the invitation to hijrah from the hijrah movement which is promoted and spread by the hijrah account and the hijrah community. This appeal is relevant with maqashid al-shariah.

\section{Conclusion}

Hijrah has two meanings. Hijrah Makaniyah is migration from one place (territorial) to another place because the destination is considered better than what will be abandoned, such as the hijrahof the Prophet with his friends and followers from Mecca to Medina in order to save himself and his religion from the threat of people who don't like it.

Hijrah also has another meaning in terms of maknawiyah, namely hijrah which isi'tiqadiyah / ta'abbudiyah. The hijrah aims to save beliefs and maintain aqidah and worship.Hijrahaqliyah strive for thinking to be brilliant with increasing knowledge so as to understand which is ordered by the Shari'a and which it forbids. Thus it does not easily affect the bad things. The hijrah of syu'uriyah keeps as much as possible to prioritize a sense of goodness by prioritizing desires that have an impact on the consequences of the world and the here after maslahat. Hijrah sulukiyah / akhlaqiyahi s a form of maintenance on acts that are relevant to the commands of Allah and the Prophet, both qauliyah and filiyah and fikriyah.

The meaning of hijrah as stated in this study is an effort to be good and try to obtain the good of the world and the hereafter, in line with the purpose of the Shari'a. As the negative things that are attached to the perpetrators of hijrah are the imperfect part of someone who is just learning religion. This is important to keep in mind by person of hijrah so it is not easy to blame people who are not in line with what is found in the journey of hijrah.

\section{References}

[1] Haikal and M. Husain, The Life of Muhammad. North American: North American Truth Publication, 1976.

[2] A. J. Qassim, Muhammad A Mercy to Allah the Nation. New Delhi, India: Goodword Books, 2001.

[3] As-Shiddiqi and Muhammad bin 'Allan, Dalilul Falihin li Thuruqi Riyadhis Shalihin. Beirut: Dar al- Kutub al-'Arabi.

[4] A. Su'ud, Islamologi. Jakarta: P.T. Rineka Cipta, 2003.

[5] A. Samiun Jazuli, Hijrah dalam Pandangan al-Qur'an. .

[6] Al-Hafidz and Ahsin W., "Kamus Ilmu al-Qur'an.".

[7] A.-D. Imasyqi and Isma'il bin Umar bin Katsir, Al-Bidayah wa al-Nihayah, 1st ed. tahqiq: Abdullah bin Abd al- Muhsin al-Turk, 1997.

[8] Al-'Aini and ' Badruddin Mahmud bin Ahmad, Umdah al-Qari Syarh Shahih alBukhari. Bairut: Darul Kutub Al-'Ilmiyyah, 2001.

[9] Al-Munawi and Z. Abdurrauf, Taisir bi Syarh al- Jami' al-Shaghir, 3rd ed. Riyadh: Maktabah Al-Imam As-Syafi'i, 1988. 
[10] M. Q. Sihab, "Tiga nilai penting hijrah Nabi." .

[11] Q. Shihab, "HIjrah itu perwujudan cinta tanah air." .

[12] A. Hair, "Fenomena Hijrah di Kalangan anak muda." .

[13] A. I. Al-Syâthibî, Al-Muwâfaqât fì Ushûl al-Syarî‘ah Jilid I. Beirut: Dâr al-Ma'rifah, 1997.

[14] al-D. al-R. Fakhr, al-mahshulfi ilmi ushul al-figh. Bairut: Dar al-kutub.

[15] Al-Daryni and Fathi, al-manahil al-Ushul iyyah fy ijtihad bi al-ra'yify al-TAisir. Dimasyq: dar al-Kitabal-Hadis, 1975.

[16] Al-Syatibi and A. Ishaq, al-Muwafaqat fi Ushul al-Syari'ah, 2nd ed. Kairo: Mustafa Muhammad, t.th., 1999.

[17] A. Abd al-Rahim, Risalah fi ri'ayah al-mashlahah li imam al-Thufy, 1st ed. al-Dar alMisriyyah al-Lubnaniyah, 1993.

[18] Al-Thufy and Najmuddin, Al-Ta'yin fi syarh al-Arba 'in. Bairut: Muassasah al-Riyan.

[19] Jokowi, "Hijrah ada proses tak bisa 1-2 Tahun.". 